\title{
Ataxia-telangiectasia paradoxes: spotlight on post-zygotic chromosome instability in the brain and its contribution to neurodegeneration pathways
}

\author{
Yuri Yurov ${ }^{1,3^{*}}$, Svetlana Vorsanova ${ }^{2,3}$, Thomas Liehr ${ }^{4}$, Ivan Yurov ${ }^{1,5}$ \\ From Molecular Neurodegeneration: Basic biology and disease pathways \\ Cannes, France. 10-12 September 2013
}

\section{Background}

Ataxia-telangiectasia is a syndrome of chromosome instability (CIN) featured by progressive neurodegeneration affecting the cerebellumin in contrast to other brain areas. Previously, progressive neuronal death in AT was hypothesized to be driven by increased post-zygotic CIN in the cerebellum [1-3]. To assess the possible involvement of neural CIN in neurodegenerative pathways we have analyzed CIN in AT brain.

\section{Materials and methods}

CIN was evaluated by high-resolution single cell (immuno-) FISH techniques in $7 \mathrm{AT}$ and 7 control samples. Bioinformatics analyses of neurodegeneration pathways were done as described earlier [4].

\section{Results}

Global aneuploidization affecting 20\% of neurons and $80 \%$ of glial cells in the prefrontal cortex and cerebellum was observed. CIN in the cerebellum has affected specific chromosomes $(7,14$, and $\mathrm{X})$ similarly the immune system. Paradoxically, dramatic and age-dependent increase in the pathological level of CIN did not result in accelerated neurodegeneration in the brain of patients, but was associated with increased lifespan. Bioinformatics analyses have shown that the SMAD pathway is implicated in neurodegeneration in addition to genome integrity maintenance, somatic $\mathrm{V}(\mathrm{D}) \mathrm{J}$ recombination and DNA damage response in neural cells.

${ }^{1}$ Mental Health Research Center, Russian Academy of Medical Sciences, Moscow, Russia

Full list of author information is available at the end of the article

\section{Conclusions}

To explain paradoxes we hypothesized that progressive neurodegeneration in the cerebellum can be associated with activation of adult neurogenesis in the diseased cerebellum and/or activation and proliferation of microglia the phagocyte system of the brain. Neurodegeneration pathways in the AT brain are likely to be applicable to disorders exhibiting neurogeneration in specific brain areas.

\section{Acknowledgements \\ Supported by BMBF/DLR (BLR 11/002), the Russian Federation President Grant (MD-4401.2013.7), RFBR 12-04-00215-a.}

\section{Authors' details}

'Mental Health Research Center, Russian Academy of Medical Sciences, Moscow, Russia. ${ }^{2}$ Institute of Paediatrics and Paediatric Surgery, Ministry of Health, Moscow, Russia. ${ }^{3}$ Moscow City University of Psychology and

Education, Moscow, Russia. ${ }^{4}$ Institute of Human Genetics, Jena, Germany. ${ }^{5}$ Department of Medical Genetics, Russian Medical Academy of Postgraduate Education, Moscow, Russia.

\section{Published: 13 September 2013}

\section{References}

1. lourov IY, Vorsanova SG, Liehr T, Yurov YB: Aneuploidy in the normal, Alzheimer's disease and ataxia-telangiectasia brain: differential expression and pathological meaning. Neurobiol Dis 2009, 34:212-220.

2. lourov IY, Vorsanova SG, Liehr T, Kolotii AD, Yurov YB: Increased chromosome instability dramatically disrupts neural genome integrity and mediates cerebellar degeneration in the ataxia-telangiectasia brain. Hum Mol Genet 2009, 18:2656-2669.

3. Yurov YB, Vorsanova SG, Tagirova MK, lourov IY: Genetic paradoxes of neurodegeneration in ataxia telangiectasia (Louis-Bar syndrome). Fundamental research 2013, 1(part 2):315-326.

4. Lourov IY, Vorsanova SG, Kurinnaia OS, Zelenova MA, Silvanovich AP, Yurov YB: Molecular karyotyping by array CGH in a Russian cohort of

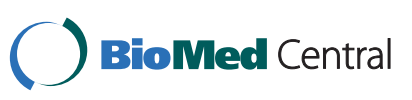

(c) 2013 Yurov et al; licensee BioMed Central Ltd. This is an Open Access article distributed under the terms of the Creative Commons Attribution License (http://creativecommons.org/licenses/by/2.0), which permits unrestricted use, distribution, and reproduction in any medium, provided the original work is properly cited. 
children with intellectual disability, autism, epilepsy and congenital anomalies. Mol Cytogenet 2012, 5:46.

doi:10.1186/1750-1326-8-S1-P51

Cite this article as: Yurov et al.: Ataxia-telangiectasia paradoxes:

spotlight on post-zygotic chromosome instability in the brain and its

contribution to neurodegeneration pathways. Molecular

Neurodegeneration 2013 8(Suppl 1):P51.

Submit your next manuscript to BioMed Central and take full advantage of:

- Convenient online submission

- Thorough peer review

- No space constraints or color figure charges

- Immediate publication on acceptance

- Inclusion in PubMed, CAS, Scopus and Google Scholar

- Research which is freely available for redistribution

Submit your manuscript at www.biomedcentral.com/submit
Ciomed Central 